\title{
Hypogenic versus epigenic subterranean ecosystem: lessons from eastern Iberian Peninsula
}

\author{
Alberto Sendra ${ }^{1,2 *}$, Policarp Garay ${ }^{3}$, Vicente M. Ortuño ${ }^{1}$, José D. Gilgado ${ }^{1}$, \\ Santiago Teruel ${ }^{2}$, and Ana Sofia P.S. Reboleira ${ }^{4,5}$ \\ ${ }^{1}$ Departamento de Ciencias de la Vida, Universidad de Alcalá, Alcalá de Henares, Spain \\ ${ }^{2}$ Asociassió per a l'Estudi del Patrimoni Subterrani, amb seu a València, Spain \\ ${ }^{3}$ Departament de Geologia. Universitat de València \\ ${ }^{4}$ Departamento de Biología \& CESAM. Universidade de Aveiro, Portugal \\ ${ }^{5}$ Departamento de Biología Animal, Universidad de La Laguna, Spain
}

\begin{abstract}
Over the last 40 years, hypogenic karst/caves have become well known and hypogene speleogenesis has been used to explain the formation of some of the largest subterranean maze caves. These hypogenic systems involve confined aquifers with upwards flow, responsible for their karstification. Such spaces begun and could be remain isolated from the surface and the contiguous subterranean habitats, including the shallow ones. We studied the invertebrate fauna and the geology/speleogenesis of two recently opened caves from Eastern Iberian Peninsula, which clearly showed features of hypogenic origin. Their scarce faunistic composition, formed by non cave-adapted fauna, is similar to other hypogenic caves from Europe and North America, suggesting that there are restrictions for faunal colonization of the hypogenic subterranean ecosystems. We propose differentiating the hypogenic from the epigenic subterranean ecosystem based on the fact that the first one lacks fauna during its genesis. This new scenario may have consequences in the regional biodiversity patterns of troglobiont species.
\end{abstract}

Keywords: subterranean ecosystem; hypogene speleogenesis; epigenic hypogenic karst caves; troglobiont fauna; biodiversity patterns

Received 13 May 2013; Revised 27 November 2013; Accepted 22 January 2014

Citation: $\quad$ Sendra A., Garay P., Ortuño V.M., Gilgado J. D., Teruel S. and Reboleira A.S.P.S., 2014. Hypogenic versus epigenic subterranean ecosystem: lessons from eastern Iberian Peninsula. International Journal of Speleology, 43 (3), 253-264. Tampa, FL (USA) ISSN 0392-6672 http://dx.doi.org/10.5038/1827-806X.43.3.2

\section{INTRODUCTION}

At the beginning of the last century, the Romanian biospeleologist Émile G. Racovitza, in his comprehensive monograph 'Essai sur les problèmes biospéologiques' (Racovitza, 1907), drew the attention to the extension of the subterranean domain, far beyond human accessibility and highlighted the connection between caves, small voids and the deeper soil layers through the fissure network. This network of interconnected spaces allows faunal migration directly across pits or sinks of water or through the shallow subterranean habitats SSHs (Culver \& Pipan, 2009a, 2009b; for more details see Camacho, 1992). The SSHs ranges from the 'upper hypogean zone' (Uéno, 1987) or 'milieu souterrain superficial' (MSS) through to caves and other non-karstificables lithologies (Juberthie et al., 1980, 1981; Gers, 1998), including the recently proposed alluvial MSS (Ortuño et al., 2013). The SSHs include, among others, the epikarst, a very superficial habitat under the surface of the karst in the infiltration zone (Bakalowizc, 2005), which is an ecotone between surface water and groundwater (Pipan, 2005); and the hypotelminorheic habitat (Meštrov, 1962; Culver \& Pipan, 2009b), a persistent shallow subsurface of wet spots fed by subsurface water in a slight depression (Fig. 1). The aquatic compartment of the subterranean ecosystem extends through the deepest aquifers such as the Edwards Aquifer in Texas (USA) at 600 to 1000 meters deep, to the shallow interstitial habitats composed of water filled spaces between unconsolidated sediments (Culver \& Pipan, 2009a). Among these subterranean compartments, the subterranean-adapted fauna can inhabit from the shallow habitats in the subsurface, through to the deepest known galleries at more than $-2000 \mathrm{~m}$ and from the giant subterranean chambers to the smallest fissures (Sendra \& Reboleira, 2012).

In the early 70's the discovery of the hypogenic karst, firstly studied in Europe and North America 


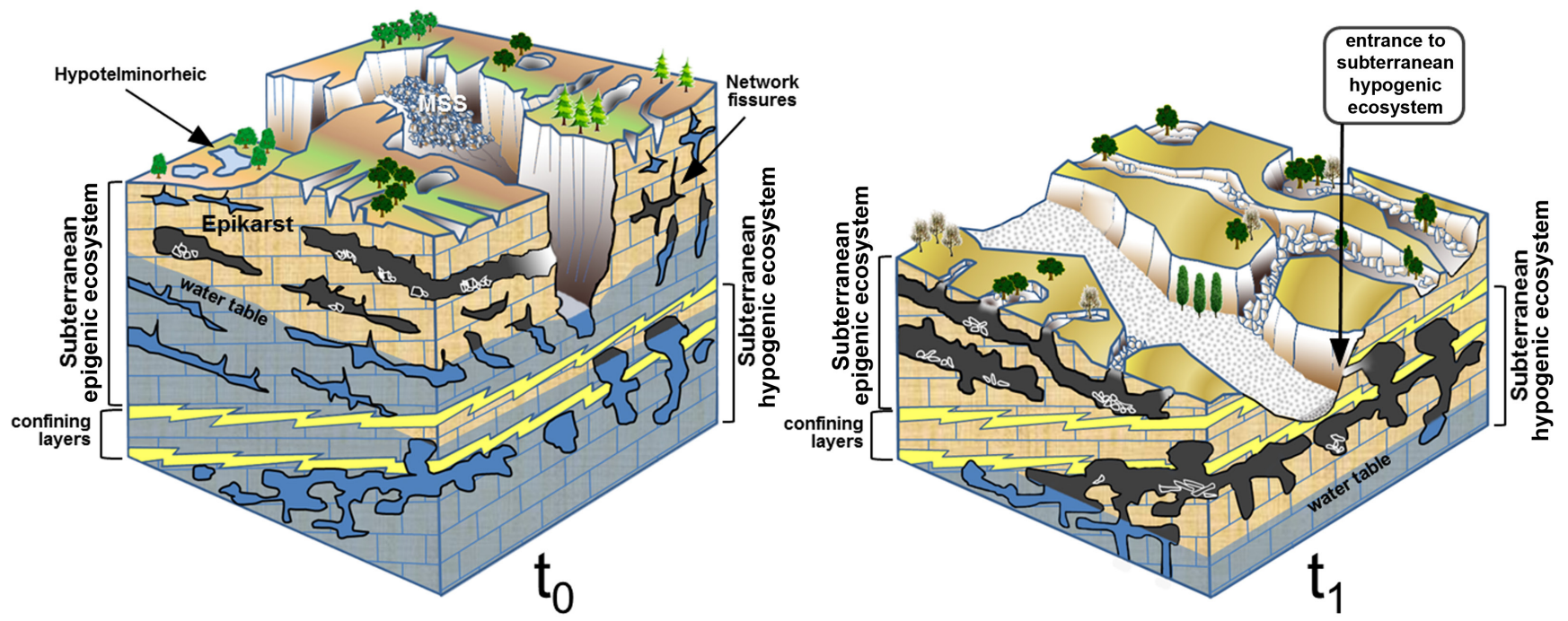

Fig. 1. Diagram of subterranean epigenic and hypogenic ecosystems: $t_{0}$ active phase and $t_{1}$ inactive phase with connection of epigenic and hypogenic ecosystems. SSH, Shallow Subterranean Habitats.

and the diffusion of hypogene speleogenesis, enabled the explanation of the formation of some of the largest subterranean maze systems around the world (Sebev, 1970; Müller \& Sarvary, 1977; Bakalowicz et al., 1987; Takács-Bolner \& Kraus, 1989; Davis et al., 1990; Klimchouk, 1990; Dublyansky, 1995). The formation of hypogenic karst/caves is explained as the result of three main genetic processes: i) Sulfidic emanations $\left(\mathrm{H}_{2} \mathrm{~S}\right)$ and their transformation into sulfuric acid, which would explain some of the largest subterranean maze systems, such as Carlsbad Caverns or Lechuguilla Cave in New Mexico, USA (see Davis et al., 1990; Palmer \& Palmer, 2000; Jagnow et al., 2000); ii) A thermal origin, such as Jewel and Wind caves in South Dakota, USA (Bakalowicz et al., 1987), in some cases including thermal fluxes with high concentrations of $\mathrm{CO}_{2}$, which is the case in the large subterranean network surrounding Buda in Hungary (Pál-Völgy, Szemló-Hegy, Castle caves, etc.) (Takács-Bolner \& Kraus, 1989) and the huge underground chambers in the Rhodope Mountains of Bulgaria (Sebev, 1970; Müller \& Sarvary, 1977; Dublyansky, 1995, 2000); iii) A deep dissolution of gypsum by upward flows under confinement conditions, as in the large caves of Optimisticheskaja, Ozernaja, Zolushka in the Podolia region in Ukraine (Klimchouk, 1990). Since 2000, hypogenic models have begun to be widely used and proposed in literature as a new type of karst genesis, quite distinct from the epigenic or classical karst/ caves (see Klimchouk et al., 2000; Klimchouk \& Ford, 2009 and several papers in a 2012 special issue of the Geomorphology journal).

Regardless of the speleogenetic processes, hypogenic karst/caves are characterized by several geomorphological features (though not always exclusive) and, especially, by being formed in confined aquifers and related to corrosive ascending fluxes: gases, acid solutions and/or thermalism. Often, those are fluxes of deep-water that locally interact with shallow water or local groundwater flow systems (Klimchouk, 2009). This new hypogenic concept allowed reconsideration of the genesis of certain previously known caves and karst systems whose origin had not been sufficiently understood yet. Thus,
Palmer (1991) estimated that the hypogenic cave systems account for only $10 \%$ of the studied cave systems, although they include some of the largest ones. Later, Klimchouk (2007) stated that hypogenic/ confined karst systems are much more widespread and that this relatively small percentage is merely an exploration bias, due to their inherent lack of accessibility from the surface. For Molerio (2004), the epigenic karst is directly controlled through karst kinetics, while the hypogenic karst responds more to a mass balance. In the same way he considers that in the epigenic karst exchange occurs with subaerial processes (water movement and mixture) and dissolution capacity is enhanced (and sometimes decreased) in the direction of flow. On the contrary, in the hypogenic karst the exchange through subaerial processes would not virtually occur, except in distal areas and those areas connected to a phreatic aquifer where dissolution capacity is generally independent of flow.

Although the knowledge of the hypogenic karst/ caves occurred relatively early, the biospeleological studies did not start until the 90's, after the discovery of a small number of sulfidic caves, many of them considered to have an hypogenetic origin. Some of them became extensively studied due to their interesting ecosystems, supported partly or totally by chemolithotrophic primary production (Sarbu, 1990, 1991; Engel et al., 2004a, 2004b; Cambell et al., 2006; Engel, 2007; Jones et al., 2008; Porter et al., 2009), in a similar way to deep-sea hydrothermal vents (Jannasch \& Wirsen, 1979). The microorganisms of these caves depend on the oxidation of chemical compounds and if they are abundant enough, they may produce enough organic matter to support a community with large organisms such as arthropods (Sarbu et al., 1996).

A previous prospection of two caves from the Eastern Iberian Peninsula revealed both their possible hypogenetic origin due to their morphological features and a remarkable lack of cave adapted fauna. Those circumstances lead us to conduct a more exhaustive study of those two caves, studying their speleogenetic origin and monitoring their fauna. The lack of 
subterranean adapted species in these studied caves, as also happens in many other hypogenic caves, leads us to propose a new insight on the colonization of the subterranean ecosystems. A discussion on the hypogenic features of Autopista and Far caves and their colonization by invertebrate terrestrial fauna is also provided.

\section{MATERIAL AND METHODS}

\section{Study sites}

The studied caves are included in the Prebaetic biospeleological district in Spain, according to Sendra et al. (2006), corresponding to the northeastern border of the Baetic Chain, near the Mediterranean Coast (Fig. 2), but far from the influence of the littoral and the Quaternary fluctuations of the sea level.

Autopista Cave (Real de Gandia, La Safor, Valencia, ETRS89, 30S X=7/42594 m, Y=43/15728 m) is located in the oriental border of Serra Falconera Mountain, a small karst area in the Eastern border of Serra Grossa hydrogeologic system (Pulido-Bosch, 1979). Several small entrances were opened during the construction of the AP7 highway in a vertical slope at more than $90 \mathrm{~m}$ a.s.1. This cave is a complex, anastomotic subterranean net, with more than $8 \mathrm{~km}$ of passages oriented SE-NW (Fig. 3), reaching the maximum depth of $-82 \mathrm{~m}$ through a wide shaft of $-40 \mathrm{~m}$ in the Alucine Pit (Grup Espeleològic Murta et al., 1987).

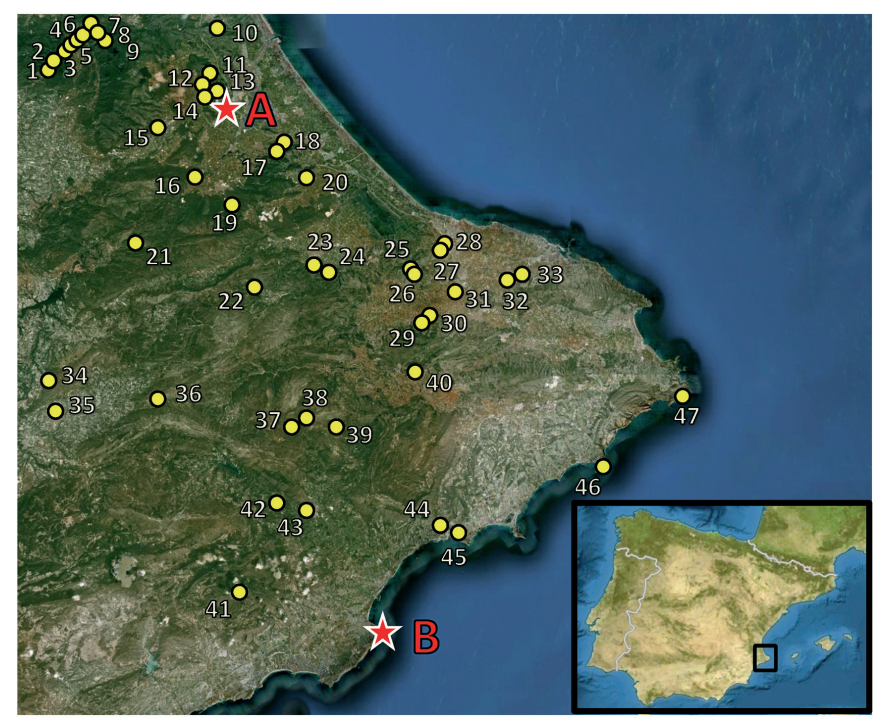

Fig. 2. A map with caves inhabited by cave-dwelling species of northeastern Prebaetic, and the locations for Autopista Cave (A) and Far Cave (B). List of caves: 1) Avenc de Quatretonda; 2) Cova de l'aigua; 3) Avenc de la Vinya Vella; 4) La Covota; 5) Cova de l'Aigua d'Engarbullers; 6) Avenc Pla dels Engarbullers; 7) Cova Fresca; 8) Cova del Perro; 9) Sima Sancho; 9) Cova dels Canellons; 10) Cova de l'Aigua; 11) Cova dels Emboscats; 12) Cova de les Maravelles; 13) Avenc del Real; 14) Cova de les Rotes Penades; 15) Cova de Soliganyes; 16) Cova de l'Angel; 17) Sima Blanca; 18) Avenc Lléngua de Sérvol; 19) Cova de l'Amuixic; 20) Cova Font dels Bassiets; 21) Cova del Rull; 22) Cova de la Mina de Luis Santonja; 23) Cova de Sant Joan; 24) Cova Bolumini; 25) Avenc de la Cigarra; 26) Cova Fosca; 27) Cova de la Pedrera; 28) L'Avenc; 29) Cova de les Calaveres; 30) Cova del Pouet; 31) Cova de la Punta de Benimaquia; 32) Cova de l'Andorial (probably destroyed); 33) Cova de Les Maravelles; 34) Cova de Barrina; 35) Avenc del Morro del Estepar; 36) Cova del Somo; 37) Avenc Gran i Petit del Frare; 38) Cova dels Morets; 39) Cova de les Meravelles; 40) Sima el Cremat; 41) Cova Massatava; 42) Cova de la Pinta Mister; 43) Mina del Capellá 44) Cova dels colombs; 45) Cova dels Rats Penats; 46) Cova Gran.

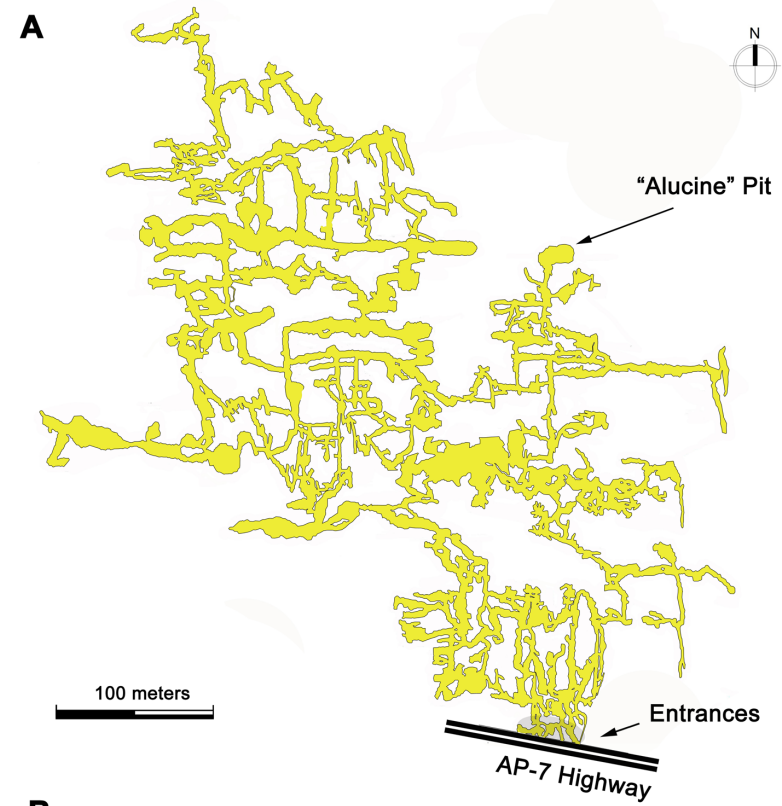

B

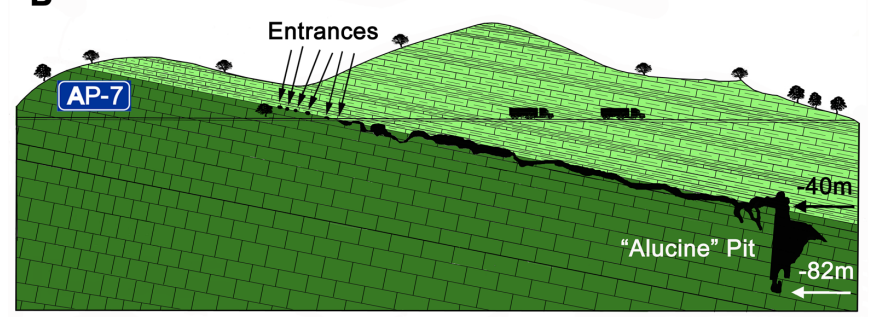

Marl and dolomite rhythmic bedding Villa de Ves formation

Doloesparites Alatoz formation

Fig. 3. Autopista Cave (Serra Falconera Mountain): A) Plan view of the cave, a hypogenic maze cave near the coast, with more than $8 \mathrm{~km}$ of passages; B) Outline of the geological scenario showing the main gallery between the entrances and the end Alucine Pit.

Far Cave (Alfás del Pí, La Marina Baixa, Alicante, ETRS89, 30S $\mathrm{X}=7 / 56426 \mathrm{~m}, \mathrm{Y}=42 / 72590 \mathrm{~m})$ is a labyrinthic network with about two kilometers of tunnels carved into the northeast slope of Serra Gelada Mountain, with a predominant E-W orientation (Fig. 4) and only accessible through one small size entrance located at 120 $\mathrm{m}$ a.s.1. (Speleo Club Covak Vila Joiosa, pers. comm.).

Both caves present some areas with constant water infiltration from the surface in some galleries or small pools. In Autopista Cave the water level rises periodically, flooding its deepest zone.

\section{Fieldwork}

The Autopista Cave was monitored from $25^{\text {th }}$ November 2011 to $10^{\text {th }}$ June 2012, near the entrance and along the main galleries. The Far Cave was monitored during two years, from $24^{\text {th }}$ June 2006 to $15^{\text {th }}$ May 2008. A set of pitfall traps $(6 \mathrm{~cm}$ in diameter and $7 \mathrm{~cm}$ in depth) was set in each cave, with a minimum separation among them of 100 meters. The traps were partially filled with 1.2-propanediol and cheese was used as bait. The pitfall sampling was supplemented by one hour of active search during each visit to the caves. One half liter of guano was processed for total extraction of fauna using Berlese (1905) method. Samples were sorted and each taxonomic group was identified.

In the Far Cave, temperature was measured using an Escort iLog Temperature Logger and in Autopista Cave 

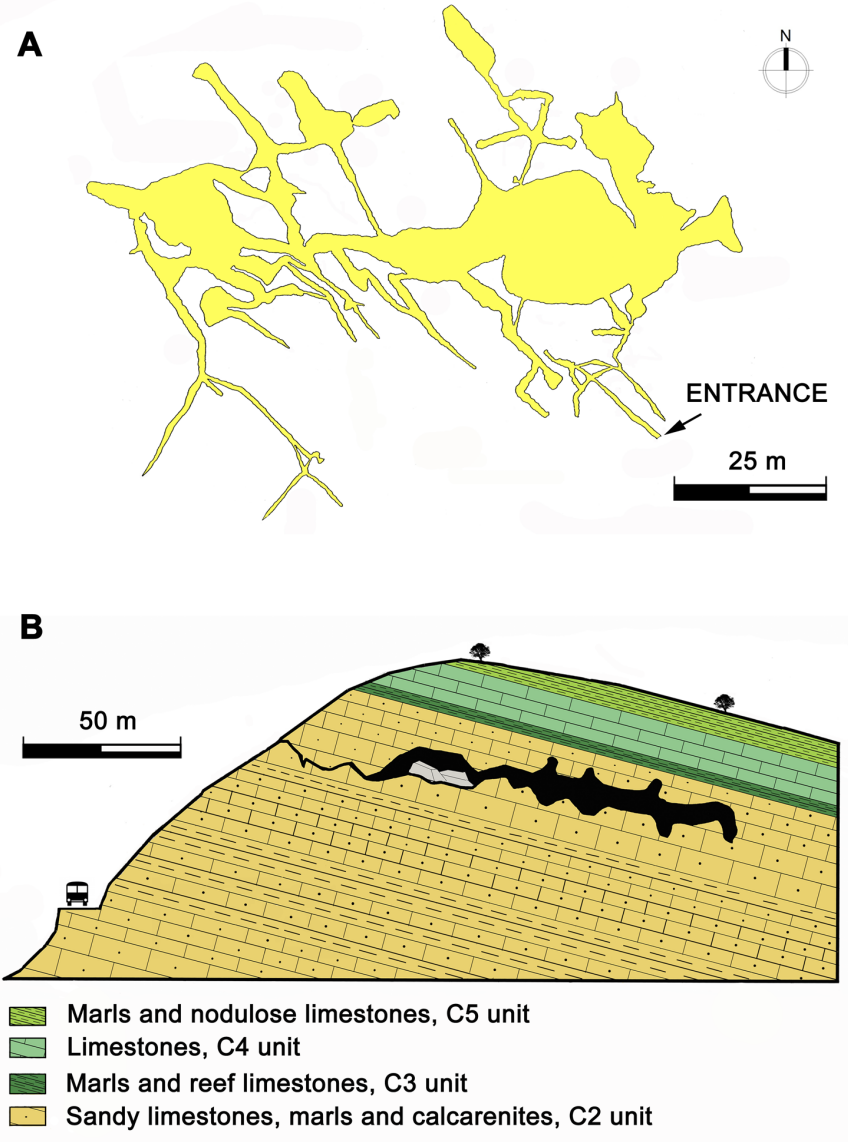

Fig. 4. Far Cave (Serra Gelada Mountain): A) Plan view of the cave, a hypogenic maze cave with $>2 \mathrm{~km}$ of passages and chambers; B) Outline of the geological scenario showing the main gallery.

with a Thermo-hygrometer Lufft (Hand Held Device E200) and the humidity of both caves with the latter device.

\section{RESULTS}

\section{Geological features of studied caves}

The Autopista Cave has developed, in its upper part, within the dolosparite of Alatoz Formation (Cenomanian), just above the contact with the marl and dolomites rhythmic bedding of Villa de Ves Formation (Cenomanian-Turonian), superimposed on it and acting as a confining layer (Figs. 3B, 5A). The dolosparite of Alatoz Formation is about $60 \mathrm{~m}$ thick and consists of massive layers of dolosparite (dolomite crystals of 100 to $200 \mu \mathrm{m}$ ), with more than $93 \%$ of carbonates. Villa de Ves Formation is over $90 \mathrm{~m}$ thick. Marls are especially abundant and dominant in the lower levels of the formation, observed in detail in some subsidences (collapses) of the ceiling (Figs. 6A \& B). Its anastomotic network has developed mainly in a slope, defining the contact between the two formations mentioned above with a dip of about 15 to $20^{\circ} \mathrm{NE}$. The geomorphology of the cavity is dominated by a maze of coalescing canals (maze cave), more or less circular and controlled by ascending corrosion forms, such as cupolas, feeders (Figs. 6D \& E), rising wall channels and anastomotic pipes and tubes, occasionally alternating with areas of collapse, where the flat roof formed by the rhythmic bedding formation has collapsed, yielding small rooms with debris cones and detached parallelepiped
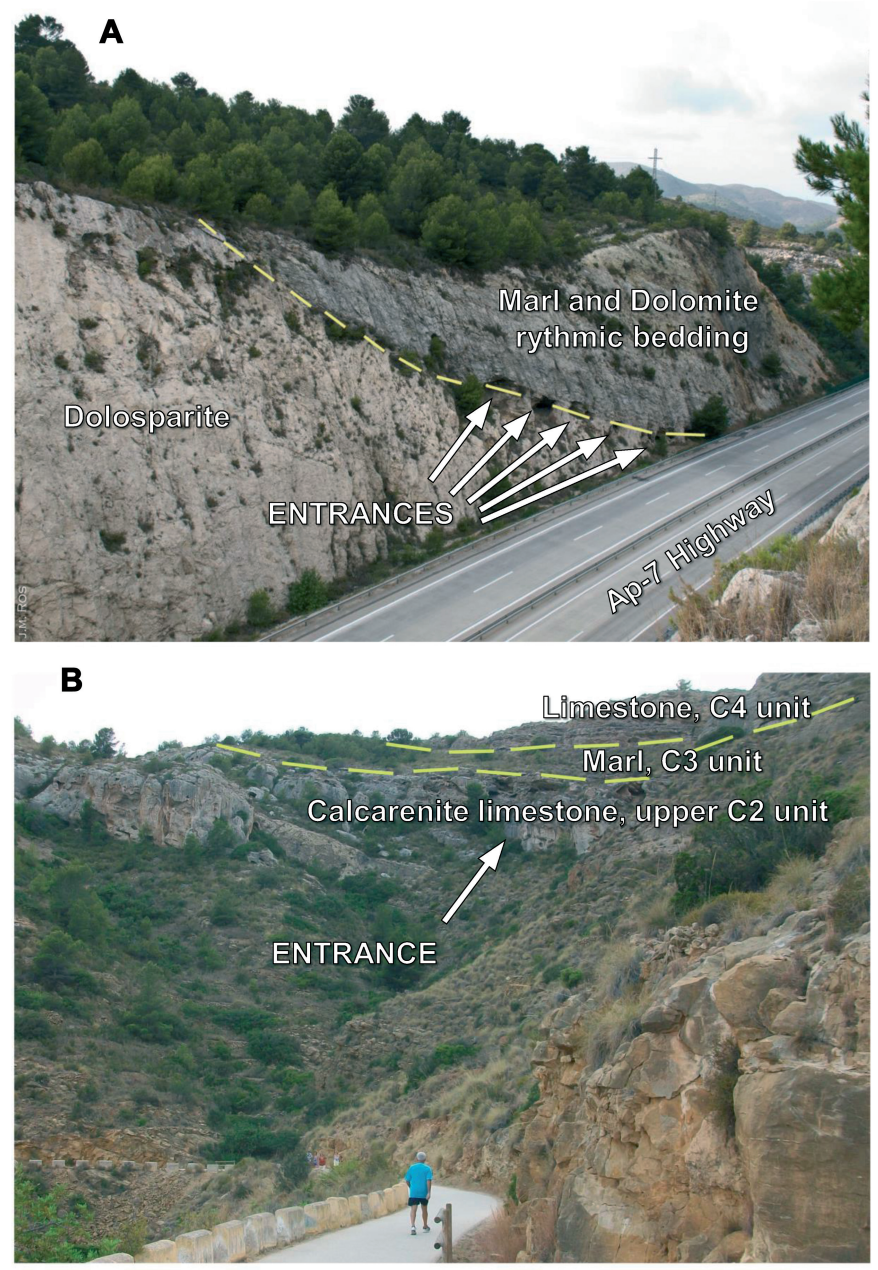

Fig. 5. A) Autopista Cave, showing the entrances opened due to the construction of the highway and also the contact between the marl and dolomite rhythmic bedding and the dolosparite in which the cave is developed; B) Far Cave, showing the slope with the entrance in the highest part of $\mathrm{C} 2$ unit and the contact between the calcarenitic limestone and the marl formation C3 unit as the confining layer.

blocks (Figs. 6A \& B), often hindering or obstructing the exploration of this subterranean network. The cave walls show some structures such as the boxwork formations through many sectors of the cave (Fig. 6F). The Alucine Pit is located in the lower section (Fig. 6C), which is considered a big feeder, the main upstream source of the currently known network. The geological structure and the regional hydrogeological framework show that the Autopista cave was formed within a dolomitic confined aquifer, located in the ascending or distal zone of the Hydrogeological Subsystem of Serra Grossa (PulidoBosch, 1979) and with hydrothermal traits. The current vadose position of the cave is consistent with the regional piezometric decline experienced by the aquifers in the area during the Quaternary.

The Far Cave is formed within a large monoclinal block of $7 \mathrm{~km}^{2}$, with NE-SW direction and westward dip, forming part of the eastern flank of the coastal syncline of Villa Joiosa, according to geologic map of Spain $n^{\circ} 848$ (Hernández et al., 2008). This syncline is occupied by the Quaternary Plain of Benidorm, which is a detrital aquifer disconnected from infra-adjacent limestone, due to the existence of Cretaceous marls, which are part of the syncline structure itself. The cave is basically a network of labyrinthine coalescent 

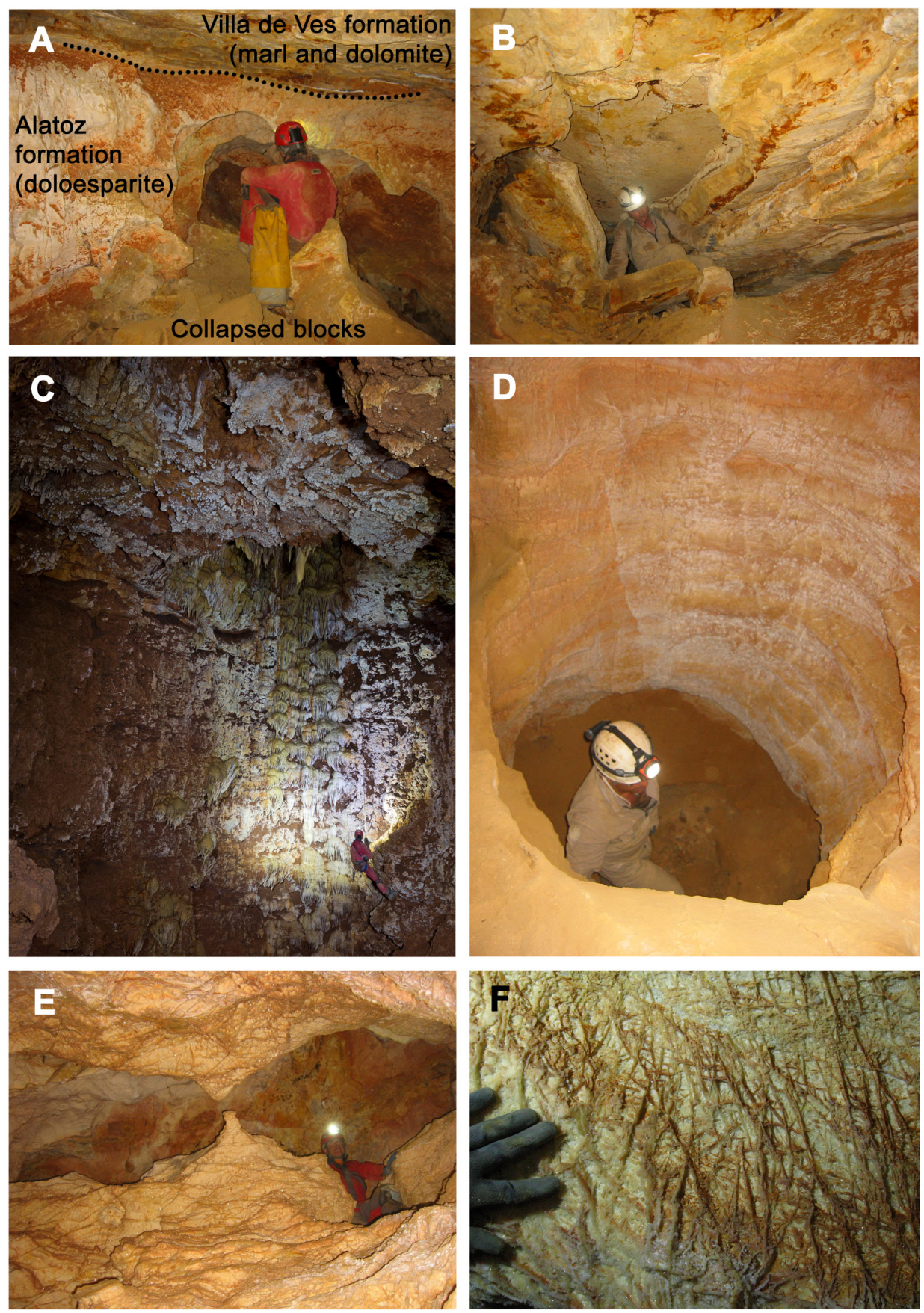

Fig. 6. Autopista Cave: A) Upper gallery showing the contact between the marl and dolomite rhythmic bedding and the dolosparite where the cave is excavated; B) Collapsed parallelepiped blocks from the ceiling of marl and dolomite rhythmic bedding; C) -40 meters Alucine Pit; D) Feeder near the entrances; E) Outlets connecting ceiling channels viewed from below; F) Boxwork formations.

ducts and often overlapping sections showing frequent spongework and vertical connections (Fig. 7A). It has a very irregular subhorizontal development, with small wells (feeders) and numerous rising domes (outlets) (Figs. 7B \& D). Micropits and pockets are also usual on the surface of the cave walls (Figs. 7E \& F). Inclined sectors are seen as a result of the dip of the strata. There are also flat roof chambers, which are sloping due to clastic processes occurring subsequent to forming the hypogenic cave, which may facilitate access to endogean fauna (Fig. 7C). It has developed within a calcarenitic limestone formation, frequently with oosparites and biomicrites of $25 \mathrm{~m}$ wide (upper Albian) and $30^{\circ} \mathrm{NW}$ dip. This calcarenitic limestone forms the higher part of $\mathrm{C} 2$ unit, a robust set, about $200 \mathrm{~m}$ of sandy limestone and marl (aquitard) and the ceiling has a marl formation (aquiclude) of about 4-8 $\mathrm{m}$ thick correspondent to the C3 unit (Yébenes, 1996, 2004) (Figs. 4B, 5B). The cave presents the typical structure of a confined aquifer, currently semi dismantled by erosion and remarkably elevated - by neotectonic and/ or eustatic processes, concerning its original saturation and confined initial genetic situation.

The subhorizontal development of the Far Cave suggests an old formation linked to the mixing zone and contact between a rising thermal flow (corrosive and gasified waters of confined aquifer) and the free and floating position of the water table in the upper part of this aquifer. This upward thermal flow would be tied to the artesian basin of the Vila Joiosa syncline, proceeding its water recharge from the extensive relief developed towards W and WNW from the mountains of Puig Campana, Aitana, and others. In addition to the rise of $\mathrm{CO}_{2}$ linked to the deep aquifer and its possible thermalism, there is another corrosive 

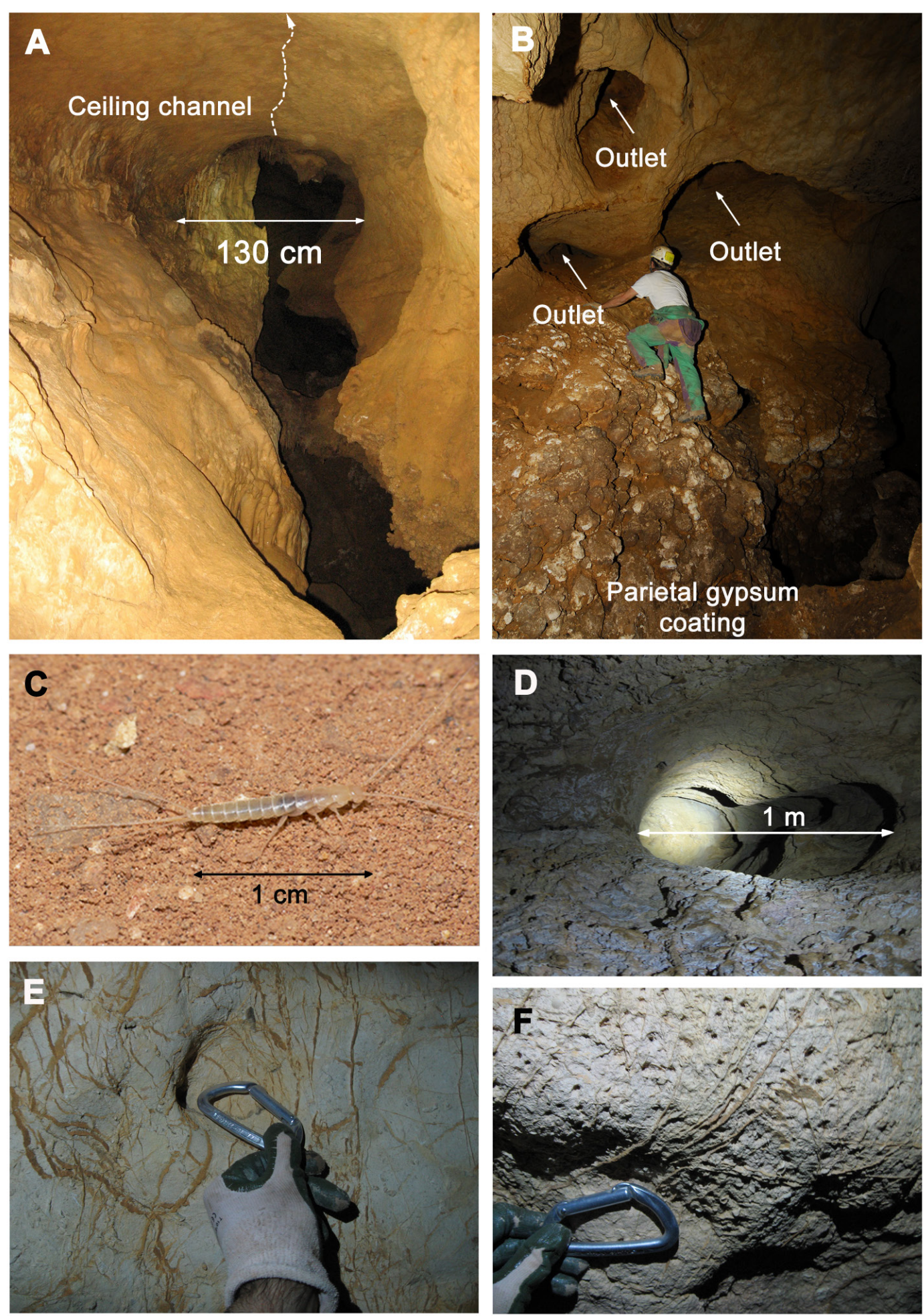

Fig. 7. Far Cave: A) Spongework gallery in the deep zone of the cave; B) Outlets in the deep zone, in a gallery with parietal gypsum coatings; C) Coletinia intermedia, a characteristic endogean frequent in the eastern chamber where roots from the surface penetrate; D) Outlet viewed from below; E) Ceiling pocket and ferruginous veins; F) Solutional micropits and ferruginous veins.

agent also involved in the hypogene speleogenesis of the cave, which may be the sulphuric acid resulting from oxidation of sulfide. This process is associated with the presence of ferric sulfide mineralization, which has been located within the host rock and, in the past, was the origin of iron ore holdings (Figs. 7E \& F). Frequently ferruginous inclusions (pyrite or marcasite transformed in siderite or hematite) are observed on the walls (Figs. $7 \mathrm{E} \& \mathrm{~F})$. Evidence supporting the action of sulfuric acid in the speleogenesis is the presence of extensive parietal gypsum coatings, identified in several sectors of the cave (Fig. 7B).

\section{Habitats and cave communities}

Due to the narrowness of both caves entrances, total darkness is reached within a few meters (Figs. 3, 4). Their mazes, horizontal in Far Cave and downward in Autopista Cave, have no appreciable airflow with the exception of some narrow passages between galleries at different levels. The air temperature ranges from 19.3 to $19.9^{\circ} \mathrm{C}$ in Autopista Cave and from 19.6 to $19.7^{\circ} \mathrm{C}$ in Far Cave, and relative humidity between $88.5 \%$ to $95.0 \%$ and 95 to $98 \%$, respectively.

No strictly subterranean fauna, considered as troglobiont exhibiting troglobiomorphic adaptations, 
was found in any of the two caves. At the entrance, the driest part of the Autopista Cave, where the relative humidity is constant and inferior to $90 \%$, the presence of epigean fauna was recorded, such as the noctuid butterfly Agrotis segetum, the phorid and sciarid flies and occasionally harvestmen of the genus Leiobunum (Table 1). After the entrance there are abundant water pools on the floor, and the relative air humidity surpasses $90 \%$ and even $95 \%$ in the deepest galleries, where wet clay soils and small pools appear. The pitfalls located in the first $200 \mathrm{~m}$ have only captured epigean fauna such as sciarid flies and occasionally, the barkfly Psyllipsocus ramburi, being less frequent between 300-500 $\mathrm{m}$ and disappearing in its northwestern sector, after $500 \mathrm{~m}$ from the entrance (Table 1).

The Far Cave has a richer fauna community with several endogean, hygrophilous and lucifugous elements spread throughout the deep area of the cave. Near the entrance, in the narrow circular conducts, there are the typical elements of parietal fauna: the noctuid butterfly $A$. segetum, the harvestmen Leiobunum, the spider Loxosceles rufescens, and the tenebrionid beetle Elenophorus collaris, probably looking for shelter from the dry surface conditions. The access to the easternmost chamber is located in the deepest area, where the ceiling is near the surface and some roots of Pistacia lentiscus appear, creating a peculiar microhabitat that harbors endogean species, such as the nicoletiid silverfish Coletinia intermedia, recently described from this cave (Molero et al., 2013) (Fig. 7C), an unidentified species of geophilomorph centipede and a gnaphosid spider. In the eastern part of this chamber, there are guano accumulations up to two meters high (although bats were not detected during explorations), that support a diverse invertebrate fauna roughly linked to the existence of guano, among them: two species of diplurans, a japygid of Japyx genus and a projapygid of Projapyx genus, a nontroglomorphic Pseudosinella springtail, two species of isopods Porcellio bolivari and Cristarmadillidium breuili previously known from other caves of this area, as well as an epigean species of sciarid fly and a polydesmid millipede. In the deepest galleries only the non-troglomorphic springtails Gisinurus malatestai, a species of Oncopodura and a species of oribatid Damaeidae mite were found (Table 1).

\section{DISCUSSION}

The karstification of hypogenic systems always involves confined aquifers and upwards flow. The hypogenic speleogenesis has different kinetics than epigenic karst since its origin lacks of surface connection. When it exists, it is always in the cessation of growth. Hypogenic karst/caves might not be the adequate name if we remember that the words "hypogenesis/hypogenic" have been used in relation to the geology of mineral deposits and endogen processes related to rising solutions and magmatic hydrothermalism. This is one of the reasons why Palmer (2011) does not share completely the concept of hypogenic karst/caves of authors such Klimchouk
$\&$ Ford (2009). For Palmer (2011) hypogenic caves are formed by upward flow of deep-seated water or by solution aggressiveness generated at great depth below the surface.

Although Autopista and Far caves were known for several decades (Grup Espeleològic Murta et al., 1987, Speleo Club Covak Vila Joiosa, pers. comm.), their hypogene speleogenetic origin has been now recognized for the first time. These two studied caves show obvious geomorphologic features of hypogenic origin. Both present reticular and maze developments typical of karstification in confined aquifers, where there is a confining layer acting as a roof and underneath an aquifer where speleogenesis occurs. Also they have many macro-morphological features due to hypogenic origin (Klimchouk et al., 2000; Klimchouk \& Ford, 2009) caused by corrosive rising flows, such as feeders developed along networks, forming typical wells where corrosive ascent flow took place, the frequent outlets or blind chimneys developed in the roof of many conducts, micropits, pockets and in general the intersecting and anastomosed ductwork sometimes overlapped, forming floors intercommunicated by feeders. Considering these features we suggest defining a new natural model, easy to distinguish from the classical epigenic karst model, as it was often defined by authors such as Eraso (1973) with their classical features such as: scallops, vertical channels, pendants, potholes or detrital sediments.

In both studied caves, there was no connection between the subterranean hypogenic conduits and the surface during their genesis, yielding a subterranean space that prevents the input of fauna and organic nutrients (MOD or MOP) from the surface. This could be the explanation for the lack of true invertebrate troglobionts (and stygobionts) and the general scarcity of fauna (remarkably clear in Autopista Cave) in the studied hypogenic caves. Moreover, Autopista and Far caves are surrounded by non hypogenic caves inhabited by troglobiont fauna. Autopista Cave is carved in a small karst massif where there are many caves habited by troglobiont leiodid beetles and diplurans (Herrero-Borgoñón \& González, 1993). Both Autopista and Far caves belong to the same karst region of the Eastern Prebaetic where at least 16 troglobiont species of arthropods are known (Zaragoza \& Sendra, 1988; Domingo et al., 2007): spider (1 spp), pseudoscorpions (3 spp), diplurans (3 species) and leiodid beetles ( $3 \mathrm{spp}$ ) and carabid beetles (4 spp) (Fig. 2).

Thirty years have passed since the connection of Autopista Cave to the surface, as a result of the construction of the AP7 highway (Valencia-Alicante) in 1983, a short period of time for cave's faunal colonization. Its scarce invertebrate fauna may be the result of the active entrance of epigean species of flies and butterflies, favored by the organic inputs left by speleological activity, particularity the presence of opportunistic barkflies. The presence of vertebrates, the bat Rhinolophus ferrumequinum (Schreber, 1774) near one of the entrances, detected by Herrero-Borgoñón \& González (1993), was not found during our study. Despite the high relative humidity (above 95\%), constant temperature and the occasional water percolation in some narrow galleries 
Table 1. Fauna of Autopista and Far caves, eastern Iberian Peninsula, Spain.

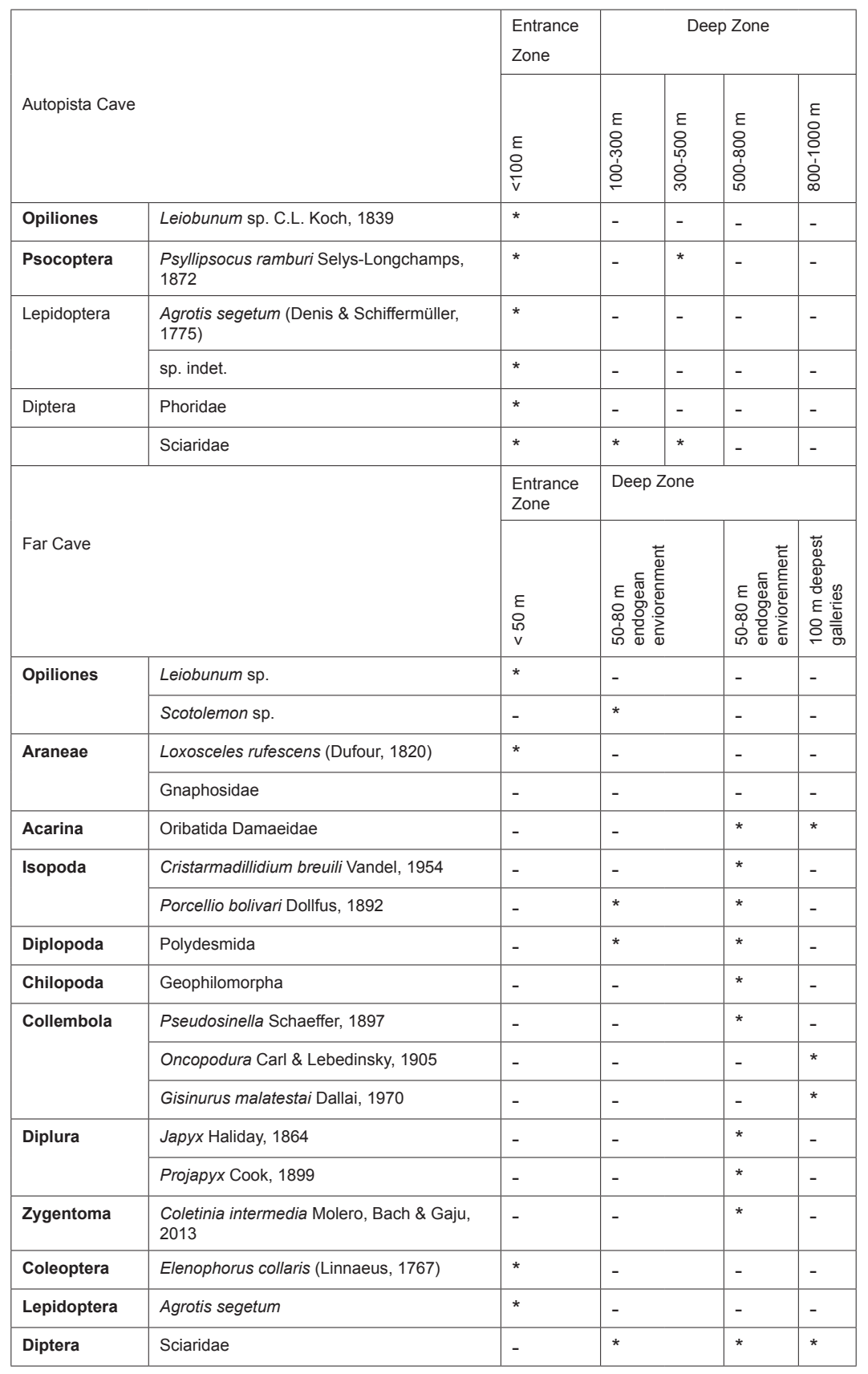

(m) meters from the entrance

was not enough to facilitate the arrival of hygrophilous species that were present only at the entrance.

Far Cave is connected to the surface due to the progressive and rapid retreat of the slope during the Late Pleistocene. There are two facts that can serve as evidence of this erosion process: i) The location of the small entrance, which opens in a distal portion of the ductwork and ii) In the same sector of the cave, the presence of colluvial deposits and hardly any loose matrix (grèzes), denoting the retreat of the mountain slope.

Although Far Cave is about $120 \mathrm{~m}$ a.s.1., the hill descends steadily to the Mediterranean Sea and presents significant accumulations of sand deposits (rampant dunes) interdigitated with slope deposits (colluvial, usually with red matrix and sometimes crusted), indicating a relatively high position of an emerged wide sandy platform. Also striking is the possible existence of a tyrrhenian fossil beach, remnants of climbing dunes identified by Navarro et al. (1959) at $170 \mathrm{~m}$ a.s.1., on the southern slope of the mountain. These data help us to understand how the confined aquifer originated several hundred or a few thousand years ago, the dismantling of the slopes and the hydrothermal disconnection. The final result is a fossil cave isolated from the surface until relatively recent times. Despite the suitable ecological conditions of Far Cave (relative humidity close to 99\%, constant temperature, presence of water in small pools, percolating water in several places within the cave and active movement of animals, especially bats), it has not been colonized by troglobiont species. However, this cave was colonized by guanophiles, endogean and hygrophilous species, facilitated by two factors: the input of bats and the temporary presence of guano, and the ease of access from the outside, particularly in the easternmost room, were roots coming from the surface are present. Noteworthy is the discovery of one species of Projapygidae family, a tropical dipluran previously 
unknown in Europe, spread through Africa and South America, and whose presence has been detected before in guano accumulation (Paulian \& DelamareDeboutteville, 1948).

Both caves have poor communication with the surface, and thus they receive small contributions from the meteoric water that could bring organic matter, which may explain how only small populations of springtails and mites can exist in its deepest parts. Invertebrate colonization is still in its incipient phase. The recent connection to the surface of both caves and their isolation during the hypogenic formation seems to have impeded the colonization by geographically close troglobiont species, allowing only very recent colonization by nonspecialized arthropods.

The lack of troglobiont fauna in Autopista and Far caves match with the fauna data in the literature of many hypogenetic caves. For example, the caves quoted in the introduction (some of them among the largest in the world), are almost without invertebrate fauna, in spite of their rich bacterial and fungi diversity (e.g., Lechuguilla Cave; Cunningham et al., 1995). The same situation is known from other caves that are longer than $200 \mathrm{~km}$, such as the Jewel Cave in South Dakota (Olson, 1977) or Optimisticheskaja and Zolushka in Ukraine, where only microorganisms have been recorded (Andrejchuk \& Klimchouk, 2001; Ridush, pers. comm.).

Nevertheless, not all sulfidic caves could be considered to have a hypogenetic origin. The karstification by sulfides does not always happen in hypogenic karst/ caves, also in epigenic ones, especially when there is oxidation of pyrite or others sulfides. Eraso (1969) refers to 10 different speleogenetic processes in epigenic karst including sulphuric acid coming from oxidation of sulfurs. As such, we can consider some sulfidic caves as not truly or completely excavated in hypogenic conditions. This is the case with Ayyalon Cave (Israel) (Por et al., 2013), which does not have (or had) a confining layer and so its colonization from the surface was always possible. It is the same case for some Italian caves considered hypogenic such as the Buso della Rana Pisatella System (Tisato et al., 2012) and the well known Frasassi Caves (Italy) (Galdenzi \& Sarbu, 2000; Sarbu et al., 2000). The Movile Cave (Romania) deserves special mention, given that it is an isolated ecosystem with a trophic web composed of 48 cave-dwelling invertebrates, 33 of them endemic to this system (Sarbu \& Kane, 1995; Sarbu, 2000). This rich community of invertebrates colonized the cavity over extensive periods of time in several distinct episodes (Sarbu, 2000) when the cave was connected to the surface before being resealed again.

On several occasions some authors write about sulfidic caves making references to their poor communication with the surface and the subterranean shallow habitats (Forti et al., 2002; Engel, 2007) but without a general consideration of the scarcity of the fauna in hypogenic karst/caves.

From these observations, the reasoning would be as follows: all subterranean hypogenic confined karst/caves must lack fauna in their active phase due to isolation (Figs. 1 and 8, phase $t_{0}$ ), although they might contain a community of chemolithotrophic microorganisms, related or not to their speleogenesis processes.
Independently of the speleogenetic of the hypogenic karst/caves, the cessation of growth of the karst/caves and the drop of the piezometric level maintain this environment without fauna until a connection with the surface or to other subterranean habitats is established. Only then, fauna may colonize hypogenic karst/caves and the entry of food resources from the surface may also be established. However, the colonization becomes difficult in deep caves embedded in solid compact rocks that could prevent the interconnection with subterranean superficial well developed habitats, if they are present (Figs. 1 and 8, phase $t_{1}$ ).

\section{FINAL REMARKS}

The classical definition of the subterranean ecosystem through bioespeleological literature, shown by Racovitza (1907), Juberthie (2000), or Culver and Pipan (2009a) may be summarized as a network of intercommunicated micro, meso and macro voids, filled or not with meteoric water, extending from the surface towards the subsurface, allowing the movement of fauna communities and nutrients mostly from the surface. Those spaces are in total darkness, with isothermal tendency, often close to saturated air humidity in the terrestrial compartment and generally low food resources. This allows the existence of troglobiont (and stygobiont) communities characterized by the absence of primary photosynthetic producers, with little presence of chemolithotrophic (except for the additional presence of sulfur or methane sources), and a more or less abundant animal community depending on the amount of nutrient input from the surface.

By considering the hypogenic karst/caves sensu Klimchouk \& Ford (2009) and their lack of fauna, we suggest the concept of a singular hypogenic subterranean ecosystem separated from the classical or epigenic subterranean ecosystem. This hypogenic subterranean ecosystem should be defined as a network of micro, meso and macro subterranean spaces, which are excavated into karst rocks in confined conditions and thus isolated from the surface, resulting in semi-climatic-independence from the surface, a temperature slightly higher due to geothermal anomalies and without input of organic nutrients from the surface. This ecosystem may harbor an exclusive oligotrophic community of chemolitotrophic microorganisms that can be very abundant in sulfur-methane rich caves. Animal colonization only occurs once the confinement barrier with the surface or with other subterranean epigenic ecosystem is temporarily or definitively removed.

Hypogenic caves include some of the world's largest caves, often lacking fauna or accommodating a poor troglobiont community. Once the hypogenic karst/ cave is opened to the surface, it might be colonized by faunal community in connection with other subterranean habitats better connected with the surface, or even by the passively carried by water or other animals (hydrochoria and zoochoria). In the case of sulfur-methane bacteria abundance, a rich faunal community can occur if the connection with 


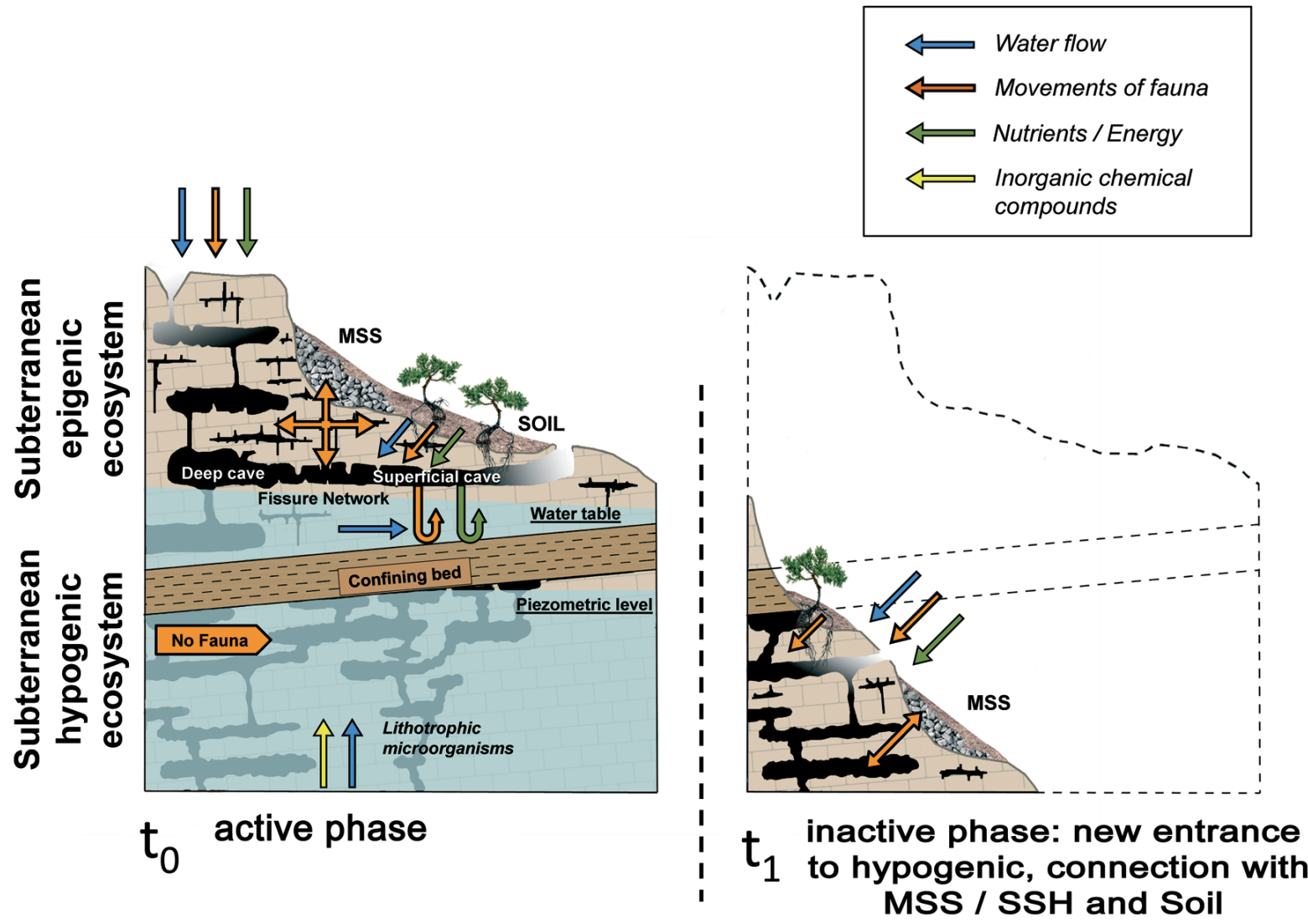

Fig. 8. Diagram of the flow of fauna, water and energy (in form of organic nutrients, or inorganic chemical compounds) in both epigenic and hypogenic subterranean ecosystems. $\mathrm{t}_{0}$ active phase; $\mathrm{t}_{1}$ inactive phase with the connection of hypogenic ecosystem with the surface, $\mathrm{SSH}$ and soil.

the epigenic subterranean ecosystem or the surface has been possible, for at least some period of time

The relation between the hypogenic karst/caves and their lack of troglobiont fauna may have relevant consequences on our knowledge of the biodiversity patterns of subterranean species. Such hypogenic karst/caves can explain the lack of troglobiont fauna in subterranean ecosystems with suitable environmental conditions, even when they are located within massifs rich in troglobiont species.

\section{ACKNOWLEDGEMENTS}

We would like to thank our colleagues for taxonomical identification of the fauna collected: Arturo Baz (Psocoptera) from the University of Alcalá, Lluc García (Isopoda) from Museu Balear, Rafael Jordana (Collembola) from the University of Navarra, Luis Subias and Uma Shtanchaev (Oribatida) from the Complutense University of Madrid, Sergio Montagud (Lepidoptera) from Valencia University, Rafael Molero and Miguel Gaju (Zygentoma) from the University of Córdoba and Alberto Jiménez-Valverde (Araneae) from the National Museum of Natural Sciences. We are grateful to José Fernandez Peris, José Manuel Ros, Silvino Vila, and Ricardo Giménez for their support during sampling period of the Autopista Cave, and for their help in the elaboration of the illustrations. We also thank Blanca Sendra and Katie Marsen for helping us to improve the translation of this article. We are particularly indebted to Oana Teodora Moldovan, for careful reading the manuscript and for helpful comments and suggestions.

\section{REFERENCES}

Andrejchuk V.N. \& Klimchouk A.B., 2001 Geomicrobiology and redox geochemistry of the karstified Miocene gypsum aquifer, Western Ukraine: The Study from Zoloushka Cave. Geomicrobiology Journal, 18: 275-295. http://dx.doi.org/10.1080/01490450152467796

Bakalowicz M.J., 2005 - Epikarst. In: Culver, D.C. \& White W.B. (Eds.), Encyclopedia of caves. Elsevier / Academic Press: 220-222.

Bakalowicz M.J., Ford D.C., Miller T.E., Palmer A.N. \& Palmer M.V., 1987 - Thermal genesis of dissolution caves in the Black Hills, South Dakota. Geological Society of America Bulletin, 99: 729-738. http:// dx.doi.org/10.1130/0016-7606(1987)99<729:TGODC $\mathrm{I}>2.0 . \mathrm{CO} ; 2$

Berlese A., 1905 - Apparecchio per raccogliere presto ed in gran numero piccoli artropodi. Redia, 2: 85-89.

Camacho A.I., 1992 - Karst. A classification of the aquatic and terrestrial subterranean environment and their associated fauna. In: Camacho A.I. (Ed.) - The natural history of biospeleology. Consejo Superior de Investigaciones Científicas, Museo Nacional de Ciencias Naturales: 57-103.

Campbell B.J., Engel A.S., Porter M.L. \& Takai K., 2006 - The versatile $\epsilon$-proteobacteria: key players in sulphidic habitats. Nature Reviews Microbiology, 4: 458-468. http://dx.doi.org/10.1038/nrmicro1414

Culver D.C. \& Pipan T., 2009a - The biology of caves and other subterranean habitats. Oxford University Press, 254 p.

Culver D.C. \& Pipan T., 2009b - Superficial subterranean habitats - gateway to the subterranean realm? Cave and Karst Science, 35 (1-2): 5-12. 
Cunningham K.I, Northup D.E, Pollastro R.M, Wright W.G. \& LaRock E.J., 1995 - Bacteria, fungi, and biokarst in Lechuguilla Cave, Carlsbad Caverns National Park, New Mexico. Environmental Geology, 25: 2-8. http://dx.doi.org/10.1007/BF01061824

Davis D.G., Palmer M.V. \& Palmer A.N., 1990 Extraordinary subaqueous speleothems in Lechuguilla Cave, New Mexico. NSS Bulletin, 52 (2): 70-86.

Domingo J; Montagud S. \& Sendra A., 2007 - Invertebrados endémicos de la Comunidad Valenciana. Conselleria de Territori I Habitatge. Generalitat Valenciana, 256 p.

Dublyansky V.N., 1995 - Speleogenetic history of the Hungarian hydrotermal karst. Environmental Geology, 25: 24-35. http://dx.doi.org/10.1007/BF01061827

Dublyansky V.N., 2000 - A giant hydrothermal cavity in the Rhodope Mountains. In: Klimchouk A., Ford D.C., Palmer A.N. \& Dreybrodt W. (Eds.). Speleogenesis: Evolution of karst aquifers. Huntsville: National Speleological Society: 317-318.

Engel A.S., 2007 - Observations on the biodiversity of the biodiversity of sulfidic karst habitats. Journal of Cave and Karst Studies, 69 (1): 187-206.

Engel A.S., Porter M. L., Stern L.A., Quinlan S. \& Bennett P.C., 2004a - Bacterial diversity and ecosystem function of filamentous microbial mats from aphotic (cave) sulfidic springs dominated by chemolithoautotrophic "Epsilonproteobacteria". FEMS Microbiology Ecology, 51: 31-53.

http://dx.doi.org/10.1016/j.femsec.2004.07.004

Engel A.S., Stern L.A. \& Bennett P.C., 2004b - Microbial contributions to cave formation: New insights into sulfuric acid speleogenesis. Geology, 32: 369-372. http://dx.doi.org/10.1130/G20288.1

Eraso A., 1969 - Mecanismos sobre la corrosión en el karst y su repercusión en la dinámica kárstica. Boletín Geológico y Minero de España, 80 (2): 146-168.

Eraso A., 1973 - New methods in Karst Investigations, Natural Models and forms convergence. Proceedings of the $6^{\text {th }}$ International Congress of Speleology, Olomuc, II: $89-108$.

Forti P., Galdenzi S. \& Sarbu S.M., 2002 - The hypogenic caves: a powerful tool for the study of seeps and their environmental effects. Continental Shelf Research, 22: 2373-2386.

http://dx.doi.org/10.1016/S0278-4343(02)00062-6

Galdenzi S. \& Sarbu S.M., 2000 - Chemiosintesi e speleogenesi in un ecosistema ipogeo: $i$ rami sulfurei delle grotte di Frasassi. Le Grotte d'Italia, 1: 3-18.

Gers, C., 1998 - Diversity of energy fluxes and interactions between arthropod communities: from Soil to Cave. Acta Oecologica, 19 (3): 205-213. http://dx.doi.org/10.1016/S1146-609X(98)80025-8

Grup Espeleologic Murta, Speleo Club Alpino Valenciano \& Club Universitario de Montaña, 1987 - Primeros resultados topográficos de la Cova de l'Autopista (Real de Gandia, La Safor). Lapiaz, 16: 48-51.

Herrero-Borgoñón J.J. \& González J.V., 1993 Aproximación a la flora y la fauna cavernícolas de La Safor (Valencia). Edita Conselleria de Medio Ambiente/Federació Territorial Valenciana de Espeleología, 150 p.

Hernández, A., Navarro, J., Estévez, A., López, M., Lendinez, A., Ramírez, J. \& Pascual, H., 2008 - Mapa Geológico de España Hoja n ${ }^{\circ} 848$ (Benidorm), (serie MAGNA), escala 1:50.000. IGME. Madrid.

Jagnow D.H., Hill C.A., Davis D.G., DuChene H.R., Cunningham K.I., Northup D.E., \& Queen J.M., 2000 - History of sulfuric acid theory of speleogenesis in the Guadalupe Mountains, New Mexico. Journal of Cave and Karst Studies 62 (2): 54-59.
Jannasch H.W. \& Wirsen C.O., 1979 - Chemosynthetic primary production at East Pacific see floor spreading centres. BioScience, 29: 592-598.

Jones D.S., Lyon E.H. \& Macalady J.L., 2008 Geomicrobiology of biovermiculations from the Frasassi cave system, Italy. Journal of Cave and Karst Studies, 70 (2): 78-93.

Juberthie C., 2000 - The diversity of the karstic and pseudokarsttic hypogean habitats in the world. In: Wilkens H., Culver D. C. \& Humphreys W. F. (Eds.) Ecosystems of the World 30: Subterranean Ecosystems. Elsevier: 17-39.

Juberthie C., Delay D. \& Bouillon M., 1980 - Extension du milieu souterrain en zone non calcaire: description d'un nouveau milieu et de son peuplement par les Coléoptères troglobies. Mémoires Biospeológiques, 7: 19-52.

Juberthie C., Delay D. \& Bouillon M., 1981 - Extension du milieu souterrain en zone calcaire. Mémoires Biospeológiques, 8: 77-93.

Klimchouk A.B., 1990 - Artesian genesis oh the large maze caves in Miocen gypsum of the western Ukraine Doklady. Akademii Nauk Ukrainskoj SSR, ser. B7: 2832 (in Russian).

Klimchouk A.B., 2007 - Hypogene Speleogenesis: Hydrogeological and Morphogenetic Perspective. Special Paper no.1, National Cave and Karst Research Institute, Carlsbad, NM, 106 p.

Klimchouk A.B., 2009 - Morphogenesis of hypogenic caves. Geomorphology, 106: 100-117.

http://dx.doi.org/10.1016/j.geomorph.2008.09.013

Klimchouk A.B., Ford D.C., Palmer A.N. \& Dreybrodt W., 2000 - Speleogenesis: Evolution of karst aquifers. National Speleological Society, Huntsville, Alabama, 527 p.

Klimchouk A.B. \& Ford D.C., 2009 - Hypogene speleogenesis and karst hydrogeology of artesian basins. Ukranian Institute of Speleology, Special Paper 1. Simferopol, $280 \mathrm{p}$.

Meštrov M., 1962 - Un nouveau milieu aquatique souterrain: le biotope hypotelminorheique. Compte Rendus Academie des Sciences, Paris, 254: 2677-2679.

Molerio Leín L.F., 2004 - Procesos de cavernamiento (espeleogénesis) en sistemas hipogénicos. Ingeniería Hidráulixa y Ambiental, 25 (2): 39-43.

Molero R., Bach C., Sendra A., Montagud S., Barranco P. \& Gaju M., 2013 - Revision of the genus Coletinia (Zygentoma: Nicoletiidae) in the Iberian Peninsula, with descriptions of nine new species. Zootaxa, 3615 (1): 1-60.

http://dx.doi.org/10.11646/zootaxa.3615.1.1

Müller P. \& Sarvary I., 1977 - Some aspects of developments in Hungarian speleology theories during the last ten years. Karszt és Barlang, Special Issue: 53-60.

Navarro A., Villalón C., \& Trigueros E., 1959 - El Cuaternario marino de la Sierra Helada (Alicante) y la tectónica reciente. Notas y Comunicaciones del Instituto Geológico y Minero de España, 56: 25-31.

Olson R., 1977 - The hypogean ecology of Jewel Cave National Monument, Custer County, South Dakota. MS Thesis. University of Illinois. $96 \mathrm{p}$.

Ortuño V.M., Gilgado J.D., Jiménez-Valverde A., Sendra A., Pérez-Suárez G. \& Herrero-Borgoñón J.J., 2013 - The "Alluvial Mesovoid Shallow Substratum", a new subterranean habitat. PloS One 8: e76311. http://dx.doi.org/10.1371/journal.pone.0076311

Palmer A.N., 1991 - Origin and morphology of limestone caves. Geological Society of America Bulletin, 103: 1-21. http://dx.doi.org/10.1130/0016-7606(1991)103<0001: OAMOLC $>2.3 . \mathrm{CO} ; 2$ 
Palmer A.N., 2007 - Cave geology. Cave Books, Dayton, 453 p.

Palmer A.N., 2011 - Distinction between epigenic and hypogenic maze caves. Geomorphology, 134: 9-22. http://dx.doi.org/10.1016/j.geomorph.2011.03.014

Palmer A.N \& Palmer M.V., 2000 - Hydrochemical interpretation of cave patterns in the Guadalupe Mountains, New Mexico. Journal of Cave and Karst Studies, 62 (2): 91-108.

Paulian R. \& Delamare-Deboutteville C., 1948 - Sur quelques insectes guanobies de la Côte d'Ivoire. Notes Biospéologiques, 2: 63-68.

Pipan T., 2005 - Epikarst - a promising habitat. Copepod fauna, its diversity and ecology: a case study from Slovenia (Europe). Založba ZRC, Ljubljana, 101 p.

Porter M.L., Engel A.S., Kane T.C. \& Kinkle B.K., 2009 - Productivity-diversity relationships from chemolithoautotrophically based sulfidic karst systems. International Journal of Speleology, 38: 27-40. http://dx.doi.org/10.5038/1827-806X.38.1.4

Por F.D., Dimentman Ch., Frumkin A. \& Naaman I., 2013 - Animal life in the chemoautotrophic ecosystem of the hypogenic groundwater cave of Ayyalon (Israel): A summing up. Natural Science, 5: 7-13. http://dx.doi.org/10.4236/ns.2013.54A002

Pulido Bosch A., 1979 - Contribución al conocimiento de la Hidrogeología del Prebético Nororiental (provincias de Valencia y Alicante). Memoria del Instituto Geológico y Minero de España, 95: 1-410.

Racovitza E.G., 1907 - Essai sur les problèmes biospéologiques. Archives de Zoologie Expérimentale et Générale, 4 série, 6, Biospéologica, 1: 371-488.

Sarbu S.M., 1990 - The inusual fauna of a cave with thermomineral Waters containing $H_{2} S$, from southern Dobrogea, Romania. Mémoires de Biospéologie, 17: 191-195.

Sarbu S.M., 1991 - Contributions to the biological investigation of the "Movile Cave": the species composition and trophic structure of the cave community and the origin of the fauna. Mémoires de Biospéologie, 18: 193-197.

Sarbu S.M., 2000 - Movile cave: a chemoautotrophically based groundwater ecosystem. In: Wilkens H., Culver D. C \& Humphreys W. F. (Eds.) - Subterranean Ecosystems. Elsevier: 319-343.

Sarbu S.M. \& Kane, T.C., 1995 - A subterranean chemoautotrophically based ecosystem. National Speleological Society Bulletin, 57: 91-98.
Sarbu S.M., Galdenzi S., Menichetti M. \& Gentile G., 2000 - Geology and biology of the Frasassi caves in central Italy: an ecological multi-disciplinary study of a hypogenic underground karst system. In: Wilkens H., Culver D. C \& Humphreys W. F. (Eds.) - Subterranean Ecosystems. Elsevier, 359-378.

Sarbu S.M., Kane T.C. \& Kinkle B.K., 1996 - A chemoautotrophic based cave ecosystem. Science 272: 1953-1955.

http://dx.doi.org/10.1126/science.272.5270.1953

Sebev D.G., 1970 - Giant caverns in Rhodopes. Rodopski Peschernjak (Chepelare), 50, 34 pp.

Sendra A., Ortuño V.M., Zargoza J.A., Montagud S., Teruel S \& Moreno A., 2006 - Una propuesta de provincias biogeográficas para los invertebrados hipogeos valencianos. Resúmenes XII Congreso Ibérico de Entomología, Alicante: 54.

Sendra A. \& Reboleira A.S.P.S., 2012 - The world's deepest subterranean community - Krubera-Voronja Cave (Western Caucasus). International Journal of Speleology, 41 (2): 221-230.

http://dx.doi.org/10.5038/1827-806X.41.2.9

Takács-Bolner K. \& Kraus S., 1989 - The results of research into caves of hydrothermal origin. Karszt és Balang (Hungary), Special Issue, 31-38.

Tisato N., Sauro F., Bernasconi S.M., Bruijn R.H.C. \& De Waele J., 2012 - Hypogenic contribution to speleogenesis in a predominant epigenic karst system: A case study from the Venetian Alps, Italy. Geomorphology, 151152: 156-163.

http://dx.doi.org/10.1016/j.geomorph.2012.01.025

Uéno S.-I., 1987 - The derivation of terrestrial cave animals. Zoological Science, 4: 593-606.

Yébenes A., 1996 - Estratigrafia y estructura de la Serra Gelada. Cuadernos de Geografia, Universidad de Valencia, 60: 201-222.

Yébenes A., 2004 - Serra Gelada. In: Alfaro P., Andreu J.M., Estévez A., Tent-Manclús J.E. \& Yébenes A., (eds.) - Geología de Alicante. Universidad de Alicante: 225-244.

Zaragoza J.A. \& Sendra A., 1988 - Fauna cavernicola de la provincia de Alicante.. In: Diputación Provincial de Alicante (Ed.). Ayudas a la Investigación 1984-1985. Instituto de Estudios Juan Gil-Albert. Volumen III: Fauna, Flora, Ciencias y Medicina. Alicante: 11-36. 